\section{Imaging apoptosis in the eye}

\begin{abstract}
Apoptosis is a form of programmed cell death that is implicated in both pathological and physiological processes throughout the body. Its imaging in vivo with intravenous radiolabelled-annexin $\mathrm{V}$ has been heralded as an important advance, with around 30 clinical trials demonstrating its application in the early detection and monitoring of disease, and the assessment of efficacy of potential and existing therapies. A recent development has been the use of fluorescently labeled annexin $\mathrm{V}$ to visualize single retinal cells undergoing the process of apoptosis in vivo with ophthalmoscopy. This has been given the acronym DARC (Detection of Apoptosing Retinal Cells). DARC so far has only been used experimentally, but clinical trials are starting shortly in glaucoma patients. Results suggest that DARC may provide a direct assessment of retinal ganglion cell health. By enabling early assessment and quantitative analysis of cellular degeneration in glaucoma, it is hoped that DARC can identify patients before the onset of irreversible vision loss. Furthermore, in addition to aiding the tracking of disease, it may provide a rapid and objective assessment of potential and effective therapies, providing a new and meaningful clinical endpoint in glaucomatous disease that is so badly needed.
\end{abstract}

Eye (2011) 25, 545-553; doi:10.1038/eye.2011.64; published online 25 March 2011

Keywords: apoptosis; imaging; retinal cell; glaucoma

\section{Introduction}

Recent meetings organized by the NEI and the FDA (13-14 March 2008 and 24 September 2010, Bethesda, MD, USA) have identified a clear and unmet need in glaucoma for methods to detect glaucomatous disease early in the disease process. ${ }^{1}$ This need has been highlighted by the discouraging results of the first neuroprotective
MF Cordeiro ${ }^{1,2,3}$, C Migdal $^{3}$, P Bloom³ ${ }^{3}$ FW Fitzke ${ }^{2}$ and SE Moss ${ }^{4}$

Phase III clinical trial in glaucoma, at a substantial cost to Allergan Inc. (Irvine, CA, USA), which lasted 7 years and ultimately failed on the primary end point - visual fields, which is currently the gold standard.

The key cell type implicated in the development of blindness in glaucoma is the retinal ganglion cell (RGC), ${ }^{2-4}$ and RGC apoptosis has been clearly identified as the earliest form of cell loss in the disease. ${ }^{5,6}$ However, it has been estimated that up to $20-40 \%$ of RGCs are lost before field defects are detected by this method, resulting in a potential 10 -year delay in diagnosis. ${ }^{7,8}$ Standard clinical tests are therefore clearly inadequate at detecting early glaucomatous visual functional deficits. $^{9}$

The DARC Technology (Detection of Apoptosing Retinal Cells) is an innovative technique that uses the unique optical properties of the eye to allow direct visualization of nerve cells dying through apoptosis, identified by fluorescent-labeled annexin V. DARC has been used in various experimental models for the in vivo analysis of RGC apoptosis. ${ }^{1,10-13}$ Recent studies suggest its potential not only in investigating the pathogenesis of glaucoma, but also in its early diagnosis, as single cell resolution may enable the detection of abnormalities in the previously regarded 'sub-clinical' stages of the disease. Furthermore, the successful use of DARC in glaucoma models to assess the neuroprotective effects of potential drugs, ${ }^{11,12,14,15}$ suggests that the technique may also be useful in patients as a tool to gauge therapeutic efficacy.

\section{Annexin V and apoptosis}

Apoptotic cell death is a major contributory factor in disease pathogenesis throughout the body, including glaucoma, where vision loss is attributed to RGC apoptosis. ${ }^{2-4}$ It is characterized by a sequence of well-described morphological and biochemical changesnamely cell shrinkage, chromatin condensation,

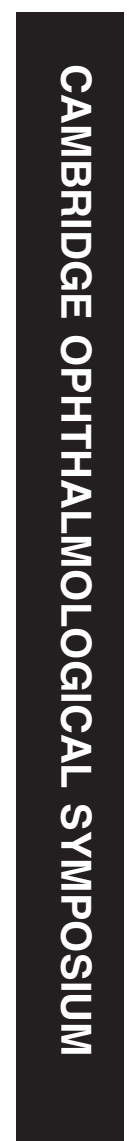

${ }^{1}$ Glaucoma \& Retinal Neurodegeneration Research Group, London, UK

${ }^{2}$ Visual Neurosciences, London, UK

${ }^{3}$ The Glaucoma Research Group, Western Eye Hospital, London, UK

${ }^{4}$ Cell Biology Departments, UCL Institute of Ophthalmology, London, UK

Correspondence: MF Cordeiro, Glaucoma \& Retinal Neurodegeneration Research Group, UCL Institute of Ophthalmology, Visual Neurosciences, Bath Street, London EC1V 9EL, UK Tel: + 44 (0)207 608 6938; Fax: + 44 (0)207 6086938 E-mail: m.cordeiro@ucl.ac.uk

Received: 30 October 2010 Accepted in revised form: 18 February 2011 Published online: 25 March 2011 
membrane blebbing, pyknotic nuclei, degradation, and fragmentation of nuclear DNA, formation of 'apoptotic bodies' and finally clearance by professional phagocytes in the absence of inflammation.

Annexin $\mathrm{V}$ is one of a large family of evolutionarily conserved proteins, members of which are biochemically and structurally defined by their ability to bind to negatively charged phospholipids such as phosphatidylserine (PS) in the presence of $\mathrm{Ca}^{2+}$. It is a $35-\mathrm{kDa}$ protein expressed in many human cells and tissues. The cDNA was cloned by several groups and shown to have the four internal tandem repeats that define proteins of the annexin family. PS is present in the inner leaflet of the plasma membrane of all mammalian cells, but early during apoptosis membrane asymmetry is lost and PS becomes externalized in the outer leaflet. Binding of annexin V to the exposed PS may therefore be used to identify apoptosis at an early stage.

Because of its properties, annexin $\mathrm{V}$ has been used for some time in the cytological detection of cells undergoing apoptosis using fluorescein isothiocyanate-labeled annexin V (FITC-annexin V). ${ }^{16}$

More recently, annexin $\mathrm{V}$ has been shown to be effective in the identification of apoptosis in vivo using radiological techniques and macroscopic fluorescent techniques. ${ }^{17-19}$ In these clinical studies, Technetium-99m $(99 \mathrm{mTc})$-radiolabeled annexin $\mathrm{V}$ was used as the targeted contrast agent in the detection of apoptosis in acute myocardial infarction, cerebral hypoxic, ishaemic brain injury, acute cardiac allograft rejection, hepatitis, lung cancer, breast cancer, lymphoma, and sarcoma. ${ }^{17-23}$ Although these techniques rely on focal areas of apoptosis being detected rather than individual cells, the use of annexin $\mathrm{V}$ in these diverse clinical settings has generated a substantial body of evidence that intravenous administration of annexin $\mathrm{V}$ is well tolerated.

Although it is theoretically possible that labeled apoptotic fragments of cells might be internalized by neighboring or migratory phagocytes in vivo, fragmentation is a late (essentially final) event, and occurs after the period during that the cells label with annexin V. Indeed, if annexin V labeling was unable to make the distinction between apoptotic cells and apoptotic bodies, it would never have become the benchmark for apoptosis assays.

\section{The DARC technology}

DARC is a non-radioactive approach that uses fluorescent-labeled annexin $\mathrm{V}$ and high-resolution imaging to enable real-time detection of the temporal dynamics of cellular apoptosis. ${ }^{1}$ DARC uses the unique optical properties of the eye that allow direct microscopic observation of cellular processes in the retina. It was originally based on the visualization of fluorescent-labeled annexin V-positive cells using an ophthalmoscope such as a confocal laser scanning ophthalmoscope (cLSO), with an argon laser of $488 \mathrm{~nm}$ necessary to excite the administered annexin V-bound fluorophore, and a photodetector system with a 521-nm cutoff filter to detect the fluorescent-emitted light. ${ }^{1,11}$ Software processing is conducted to compensate for eye movements and to optimize the signal to noise ratio. ${ }^{24,25}$

Although DARC will soon be tested for the first time in a glaucoma clinical trial, (ISRCTN59484478), all studies so far have used experimental models. ${ }^{1,11-14,26,27}$ For imaging, wide-field retina images are acquired and assessed for fluorescence using a method we have previously described. ${ }^{28}$ The total number of apoptosing RGCs for each time point in vivo is then calculated (Figure 1), ${ }^{13}$ to create a 'DARC count'.

\section{Presence of retinal ganglion cell apoptosis in glaucoma}

The presence of RGC apoptosis has been identified in specimen eyes from glaucoma patients and a variety of different experimental models of glaucoma where it has been shown to be an early event, ,3,5-7,29-32 but before the development of DARC, evidence for apoptotic RGC

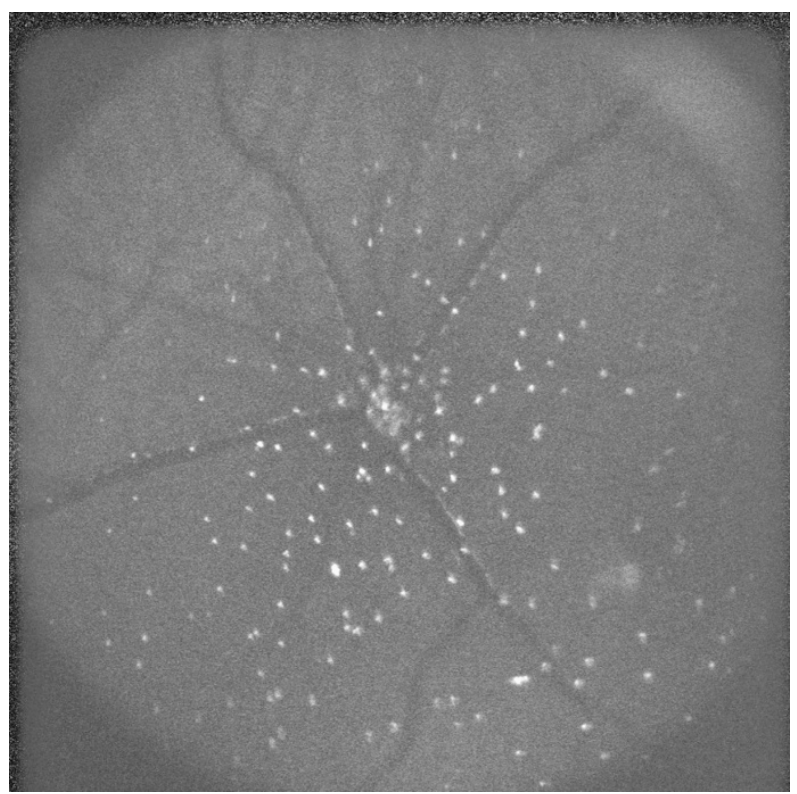

Figure 1 The retina of a rat with chemically induced apoptosis $2 \mathrm{~h}$ previously is shown with a wide-field lens. Each white spot is an individual RGC undergoing apoptosis, providing a snapshot of the level of RGC death at one time. Apoptosing retinal ganglion cells are identified by a fluorescently labeled annexin $\mathrm{V}$ marker - the whole technique is given the acronym DARC (Detection of Apoptosing Retinal Cells). 
death had been restricted to histological and post-mortem analysis. . $3,7,29,30$

RGC loss is a well-documented sequelae of elevated intraocular pressure (IOP) in experimental glaucoma models. Several models of ocular hypertension have been developed in the rat, of which the technique first described by Morrison et al,,$^{33-37}$ and used by us, has become the most popular. The development of RGC loss in these models has been chronicled with peak RGC loss of around 30-40\% occurring at 1 month after IOP elevation. ${ }^{2,3,35,38-41}$ RGC apoptosis is believed to occur predominantly in the early phase of RGC loss in rat $\mathrm{OHT}^{2,3,5-7,29-32}$ possibly as a pressure-related response. $^{42,43}$

The level of RGC loss and RGC apoptosis as a function of ageing and disease has been previously estimated though is not well established. Zeyen ${ }^{8}$ has discussed that the rate of ganglion cell attrition due to normal human aging is $\sim 0.4 \%$ loss per year, and this is supported by several other publications, ${ }^{44-47}$ whereas that due to glaucoma is estimated as up to $4 \%$ per year. The estimated increase in RGC loss in glaucoma is strongly supported by experimental data. ${ }^{48,49}$ Assuming that early visual field defects may be identified after a loss of $\sim 40 \%$ of RGCs, this equates to an approximate 10-year delay in the detection of abnormalities by standard perimetry. ${ }^{8}$

Quigley et $a l, 3$ reported that in monkeys, $4-13 \%$ of all RGCs were undergoing apoptosis in the 2-4 weeks immediately following experimentally induced glaucoma, with sustained IOP giving rise to a prevalence of $1 \%$ RGC apoptosis. In the same paper, there was a discrepancy in the detection rates of apoptosis with different methods, with at least a 10-fold difference between light microscopy methods compared with terminal deoxynucleotidyl transferase dUTP nick end labeling (TUNEL) analysis taken by authors to reflect the brief time window during which cells are TUNEL-positive. Not withstanding the limitations of this model of glaucoma, the authors calculated that $\sim 1200$ TUNEL-positive cells are present at any given time, against an incidence of RGC apoptosis $<0.04 \%$ in control retinas. RGC apoptosis in post-mortem specimens from patients with glaucoma has been confirmed, ${ }^{4,50}$ though accurate percentage counts cannot be established with confidence because of the variables of post-mortem artefact.

\section{DARC experimental glaucoma studies}

DARC has been used in several different glaucomarelated animal models with induced RGC apoptosis. Using these models, changes in RGC apoptosis have been recorded over hours, days, and months, with evidence that the extent of cell death depends on the magnitude of the initial apoptotic inducer. We have confirmed in vivo using DARC that RGC apoptosis occurs early in these models of glaucoma, and its presence has been validated histologically with annexinpositive cells identified by DARC colocalizing with RGC labeling. ${ }^{1,10,11}$

In a well-established rat model of chronic OHT, $1,10,11$ RGC apoptosis was demonstrated with DARC in vivo and validated histologically, and shown to account for 1 , $15,13,7$, and $2 \%$ of total RGCs, with RGC losses of 17, 22, 36,45 , and $60 \%$ of the original population at $2,3,4,8$, and 16 weeks, respectively. This was in comparison with an optic nerve transection rat model, where RGC apoptosis levels were recorded as $0.3,1,8$, and $3 \%$ of total RGCs, with RGC losses of $0,3,40$, and $76 \%$ at $0,3,7$, and 12 days, respectively. These results were obtained from a large cohort of animals - with minimal intra- and inter-animal variability, reinforcing the reproducibility and repeatability of the DARC technique.,10,11

A major drawback in the management of glaucoma has to date been the lack of an accurate and sensitive method of diagnosis and monitoring treatment efficacy. DARC has been shown to provide a test of efficacy for neuroprotective treatments in several models of glaucoma. ${ }^{11,12,15,51}$ In fact, the most immediate potential benefit of DARC will be in its application to directly monitor the effects and efficacy of therapy in glaucoma. A particular advantage will be the ability to assess the effects of therapy on the DARC count after just days and weeks, rather than the years that it currently takes to obtain meaningful clinical end points.

As discussed above, methods for the early diagnosis of glaucoma are at present unsatisfactory, with significant vision loss having already occurred before patients are identified. In addition, the current use of IOP both as a diagnostic tool and as an index of control is insufficient. Studies have established there to be a wide range of IOP in glaucoma, with low IOPs not necessarily excluding the presence of glaucomatous damage, and recent evidence of progressive visual field loss despite normalization of IOP in patients treated with pressure-lowering strategies. $^{52,53}$

Non-IOP-lowering treatments have thus become a key research area in glaucoma. Currently, the best-known neuroprotective agents are modifiers of the glutamate pathways. Excessive activation of glutamate receptors on release of glutamate from injured RGCs is heavily implicated in the development of RGC apoptosis and loss in glaucoma. ${ }^{54}$ Inhibition or blockade of glutamate activity via modulation of its receptors has been advocated as an important strategy for neuroprotection in glaucoma, and in particular the modulation of NMDA (N-methyl-D-aspartate) -type glutamate receptors. NMDA antagonists have been been advocated as 
effective in preventing neuronal degeneration in neurological disorders such as Alzheimer's disease. ${ }^{55,56}$ Memantine is currently the best known NMDA antagonist with preclinical demonstration of its efficacy in experimental models of glaucoma disease. ${ }^{57,58}$ The full results of the Phase III clinical trial of POAG patients with Memantine have still not been published. However, this recent trial demonstrates the problem with current definitions of end points in glaucoma-IOP could not be used, so visual fields and optic disc changes have been used, accounting for the long period of follow-up (5 years) necessary for this trial.

Glutamate modulation is not the only mode of neuroprotection, and DARC has been used to assess new strategies, such as those targeting the Alzheimer protein $\beta$-amyloid. ${ }^{12}$

\section{Potential challenges and solutions of translating DARC to clinic}

How many apoptosing RGCs may be detected at any one time?

With the clinical studies of intravenous DARC due to start soon, attempts have been made to predict expected levels of RGC apoptosis in glaucoma patients at different stages of the disease. This is not straightforward and can only be conducted on a hypothetical basis by extrapolation from experimental and histological data, as there are no human data available. But, until the first patients are clinically assessed using DARC, these methods for modeling the disease and their predictive values are all that are available.

In the rat model of experimental glaucoma, RGC loss has been well-documented to change over time, , $^{2,35,38-41}$ and this has been confirmed using DARC, with a clear profile in the development of RGC apoptosis after elevated IOP. ${ }^{1}$ (Figure 2). By converting rat into human years, ${ }^{59}$ it is possible to estimate, in terms of disease progression in human years, an equivalent profile that may be applied to a hypothetical clinical situation.

In this hypothetical model, a sudden onset and development of the glaucomatous disease process is represented in a patient aged 50 years. Superimposing the extrapolated profile of RGC apoptosis shown in Figure 2, Table 1 shows estimates of the levels of RGC apoptosis per year and per day, including an estimate of the apoptosis rate due to normal ageing $(0.3 \%)$, and compares this with the estimated RGC apoptosis rate in an age-matched glaucoma patient. The bottom two rows I Table 1 provide actual numbers of cells predicted to die by apoptosis per day, according to the model.

From this hypothetical model, it can be seen that for a period of 10 years from the onset of disease, the daily

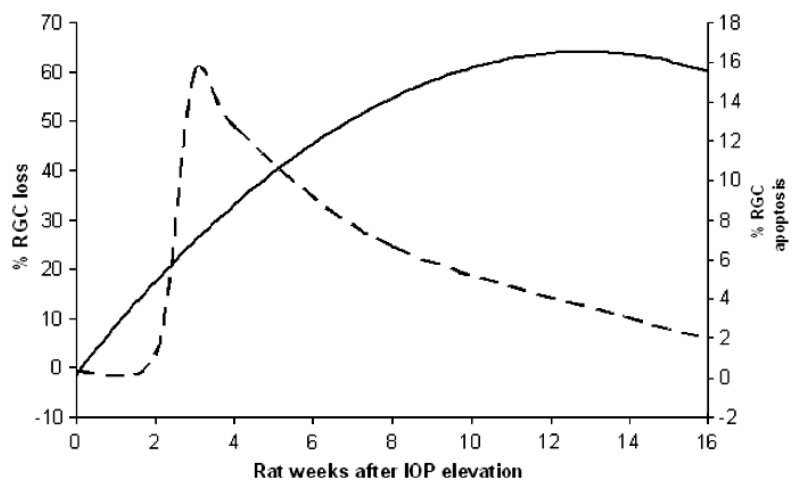

Figure 2 The profile of RGC loss (bold line) and RGC apoptosis (dashed line) has been clearly documented in the rat OHT model of experimental glaucoma, and is shown above. Note the level of peak RGC apoptosis is at 3 weeks after elevated IOP, whereas maximal levels of RGC loss occur well after that, suggesting that RGC apoptosis is an early marker of disease.

count of apoptosing RGCs (the DARC count) would be clearly much greater than that in an age-matched normal eye-ranging from 22 to 416 cells per day compared with 8 . Furthermore, this 10 -year period coincides exactly with the time-lag currently estimated as the delay in visual field perimetry detecting abnormalities 8 - providing further support for the application of DARC in the detection and diagnosis of early glaucoma.

\section{How safe and invasive is the technology?}

Annexin $\mathrm{V}$ has been used intravenously in up to 30 clinical trials, with none of them showing any adverse effects. All these trials have used intravenous radiolabeled annexin, and are summarized in Table 2.

The first DARC trials will be with intravenous fluorescently labeled annexin $\mathrm{V}$, based on the fact that the intravenous route has been used repeatedly in all the annexin V clinical trials described above. Furthermore, intravenous administration is an accepted route of administration in ophthalmology for example, fluorescein and indocyanide green angiography. However, refinement of a topical version of DARC is currently being worked upon, which would allow the technology to be totally non-invasive.

The conjugation of annexin with a fluorescent tag makes the DARC agent regarded as a new drug substance. The lead up to the Phase 1 clinical trial includes rigorous and robust safety and toxicology testing, under strict MHRA guidelines. Annexin V is a ubiquitous, endogenous and predominantly intracellular protein in humans, and therefore, distinct from an antibody, unlikely to incite an immunological reaction. There are some people with antiphospholipid syndrome 
Table 1 Estimates of RGC are shown in a hypothetical case of a patient with sudden onset of glaucoma at 50 years

\begin{tabular}{|c|c|c|c|c|c|c|c|c|}
\hline Onset age 50 years & 50 & 51 & 52 & 53 & 55 & 60 & 70 & 80 \\
\hline Hypothetical \% RGC apoptosis (rat OHT model) & 0.3 & 1.151 & 15.38 & 12.65 & 6.687 & 1.95 & 1.95 & 1.95 \\
\hline RGC count based on glaucoma $4 \%$ RGC loss/year $\left(\times 10^{3}\right)$ & 1000 & 960 & 922 & 885 & 815 & 665 & 442 & 290 \\
\hline RGC count based on glaucoma loss due to apoptosis $\left(\times 10^{3}\right)$ & 1000 & 996 & 989 & 894 & 611 & 407 & 328 & 264 \\
\hline Estimated RGC apoptosis/year & 3000 & 11467 & 152121 & 113092 & 40876 & 7934 & 6387 & 5142 \\
\hline Estimated glaucoma RGC apoptosis/day (DARC count) & 8 & 31 & 416 & 309 & 112 & 22 & 17 & 14 \\
\hline Estimated normal $0.3 \%$ RGC apoptosis/day & 8 & 8 & 8 & 8 & 8 & 8 & 8 & 7 \\
\hline
\end{tabular}

The RGC apoptosis count estimates are calculated from extrapolating the profile from the rat OHT model (Figure 2). Both yearly and daily (DARC count) levels of predicted RGC apoptosis are given in a hypothetical glaucoma case and compared with estimates of age-matched normal.

and lupus who have anti-annexin $\mathrm{V}$ antibodies, although their exact role is unknown.

\section{Is the technology sensitive enough to detect small numbers of apoptosing RGCs?}

As one would expect of a novel technology, DARC has evolved and been refined since its original development to achieve better and more accurate resultsmodifications include not only improving and optimising the methods of labeling and protein identification, but also parallel alterations to the specification and functionality of the instrumentation.

This has meant, for example, imaging with a wide-angle lens (Figure 1), the selection of different wavelengths to enhance signal-to-noise, and improving the correlation of the in vivo and histology counts. ${ }^{13,51}$

As hypothesized in Table 1, it is anticipated that DARC will provide a snapshot of the number of apoptosing RGCs at any one time-giving rise to a DARC count. Large population-based studies will be needed to establish the DARC count in relation to glaucoma and the normal ageing process, to validate the estimates above.

\section{How will DARC distinguish between ageing and other causes of retinal neurodegeneration?}

The hallmark of glaucoma is the presence of optic disc cupping with a characteristic pattern of visual field loss. The typical arcuate field loss is attributed to focal damage around the papillo-macular bundle. The presence of these focal changes is a feature of glaucoma, and allows it to be distinguished from other causes of RGC loss, such as ageing and neurodegeneration.

Only the planned clinical studies will reveal whether apoptosis occurs in the pattern of retinal nerve fibre defects - as the studies of experimental glaucoma used to date in the exemplification of DARC were performed in animals that lack a macula. It would not be inconceivable to imagine this to be the case, and therefore the increased probability of detecting focal areas of increased DARC activity in the papillo-macular bundle.
Another potential challenge is whether DARC will be able to distinguish between glaucomatous and agerelated cell death. Experimental studies to date have suggested that apoptosis in glaucoma is confined to the RGC layer, 2,3,7,30,31,60,61 including our own using DARC $^{1,10-13}$ with little evidence of age-related apoptosis in other layers. There is recent work reporting that cell loss occurs to some extent in all retinal layers in humans in normal ageing. ${ }^{62}$ We have shown recently that DARC can visualize INL bipolar apoptosis, ${ }^{51}$ but this was in a retinal laser-photocoagulation as opposed to a glaucoma or age-related model. Perhaps the most relevant agerelated model in glaucoma is the DBA transgenic model, where Jakobs et $a l^{61}$ clearly showed no bipolar or INL neuronal degeneration. Using the same model Reichstein et $a l^{31}$ concluded: '... the annexin $\mathrm{V}$ labeling procedure is reliably specific for RGCs ... in glaucomatous DBA retina', which is supported by our own experimental findings. Until the DARC clinical studies are underway, however, it is unclear how or whether apoptotic non-RGCs may affect the DARC count.

\section{DARC and the future}

Although annexin $\mathrm{V}$ has been widely used to monitor tissue apoptosis in disease, DARC is unique in that it permits in vivo resolution, and real-time non-invasive imaging, of single cells undergoing apoptosis. The application of DARC to directly observe single nerve cell apoptosis in experimental neurodegeneration, if desired in combination with other spectrally distinct cell markers, thus provides an opportunity for the investigation of fundamental disease mechanisms and the evaluation of interventions with clinical applications. Investigation of such mechanisms within the eye may shed light on mechanisms underlying neurodegeneration within the brain.

The applications of DARC thus include its use in glaucoma as a powerful new clinical tool with which to diagnose and identify patients with early disease, before they lose vision. Furthermore, it may serve as a biomarker, providing rapid information that could 
Table 2 Summary of Clinical Trials with Intravenous Anx (Anx)

\begin{tabular}{|c|c|c|c|c|c|}
\hline & Trial disease area & $\begin{array}{l}\text { No. of } \\
\text { patients }\end{array}$ & Imaging agent & Dose & Reference \\
\hline 1 & Acute myocardial infarction & 7 & $\begin{array}{l}(99 \mathrm{~m}) \mathrm{Tc}-(\mathrm{n}-1-\mathrm{iminno}-4- \\
\text { mercaptobutyl)-Anx (I-Anx) }\end{array}$ & $1.0 \mathrm{mg}$ iv & Hofstra L et al. ${ }^{63}$ \\
\hline 2 & Cardiac allograft rejection & 18 & I-Anx & $\begin{array}{l}0.5-1.0 \mathrm{mg} \text { iv } \\
\text { in } 10 \mathrm{ml}\end{array}$ & Narula J et al. ${ }^{17}$ \\
\hline 3 & Cardiac tumour & 1 & I-Anx & & Hofstra L et al. ${ }^{64}$ \\
\hline 4 & $\begin{array}{l}\text { Lung cancer } \\
\text { Lymhoma } \\
\text { Breast cancer }\end{array}$ & $\begin{array}{r}10 \\
3 \\
2\end{array}$ & I-Anx & $1.0 \mathrm{mg}$ iv & Belhocine $\mathrm{T}$ et al..$^{65}$ \\
\hline 5 & $\begin{array}{l}\text { Myocardial infarct } \\
\text { Heart failure } \\
\text { Other heart dis. } \\
\text { Healthy }\end{array}$ & $\begin{array}{r}12 \\
4 \\
3 \\
1\end{array}$ & $\begin{array}{l}\text { I-Anx } \\
(99 \mathrm{~m}) \mathrm{Tc}-(4,5 \text {-bis (thioacet } \\
\text { amido)pentanoyl)-Anx } \\
\text { (B-Anx) }\end{array}$ & $\begin{array}{l}1.0 \mathrm{mg} \text { iv } \\
\text { in } 2.5 \mathrm{ml} \\
0.8 \mathrm{mg} \text { iv } \\
\text { in } 7 \mathrm{ml}\end{array}$ & Boersma $\mathrm{HH}$ et al. ${ }^{66}$ \\
\hline 6 & Healthy & 6 male & $\begin{array}{l}\text { 99mTc-hydrazinonicotinamido } \\
\text { (HYNIC)-Anx }\end{array}$ & $25 \mu \mathrm{g}$ iv & Kemerink GJ et al. ${ }^{67}$ \\
\hline 7 & Head and neck cancer & 20 & (HYNIC)-Anx & ? & van de Wiele $\mathrm{C}$ et al..$^{68}$ \\
\hline 8 & Healthy & 6 & ${ }^{123} \mathrm{I}-\mathrm{rh}-\mathrm{An} x$ & $940 \mu \mathrm{g}$ iv & Lahorte CM et al. ${ }^{69}$ \\
\hline 9 & Myocardial infarction & 9 & B-Anx & c. $1 \mathrm{mg}$ iv & Thimister PW et al. ${ }^{70}$ \\
\hline 10 & Head and neck cancers & 33 & (HYNIC)-Anx & $?$ & Kartachova $\mathrm{M}$ et al..$^{71}$ \\
\hline 11 & Athero-sclerosis & 4 & (HYNIC)-Anx & $?$ & Kietselaer BL et al. ${ }^{72}$ \\
\hline 12 & Head and neck cancers & 13 & (HYNIC)-Anx & $0.25 \mathrm{mg} ?$ & Vermeersch $\mathrm{H}$ et al. ${ }^{73}$ \\
\hline 13 & Head and neck cancers & 18 & (HYNIC)-Anx & $0.25 \mathrm{mg} ?$ & Vermeersch $\mathrm{H}$ et al..$^{74}$ \\
\hline 14 & Head and neck cancers & 28 & (HYNIC)-Anx & $0.25 \mathrm{mg} ?$ & Vermeersch $\mathrm{H}$ et al. ${ }^{75}$ \\
\hline 15 & Follicular lymphoma & 11 & (HYNIC)-Anx & $?$ & Haas RL et al. ${ }^{76}$ \\
\hline 16 & $\begin{array}{l}\text { Healthy Ischaemic } \\
\text { muscle pre-conditioning }\end{array}$ & 44 & (HYNIC)-Anx & $\begin{array}{l}0.1 \mathrm{mg} \\
\text { ischaemic } \\
\text { infusion }\end{array}$ & Rongen GA et al. ${ }^{77}$ \\
\hline 17 & Dementia & 12 & (HYNIC)-Anx & $?$ & Lampl Y et al. ${ }^{78}$ \\
\hline 18 & Acute stroke & 12 & (HYNIC)-Anx & $0.25 \mathrm{mg}$ iv & Lorberboym M et al..$^{79}$ \\
\hline 19 & $\begin{array}{l}\text { Treatment-induced } \\
\text { normal tissue (cancer) }\end{array}$ & 18 & (HYNIC)-Anx & $?$ & Kartachova MS et al..$^{80}$ \\
\hline 20 & Lung cancer & 16 & (HYNIC)-Anx & ? & Kartachova MS et al..$^{81}$ \\
\hline 21 & $\begin{array}{l}\text { Heart failure } \\
\text { Healthy }\end{array}$ & $\begin{array}{l}9 \\
2\end{array}$ & (HYNIC)-Anx & $0.25 \mathrm{mg}$ iv & Kietselaer BL et al. ${ }^{82}$ \\
\hline 22 & Crohn's Disease & 14 & (HYNIC)-Anx & ? & Van den Brande JM et al. ${ }^{83}$ \\
\hline 23 & $\begin{array}{l}\text { Outcome prediction } \\
\text { cancer treatment }\end{array}$ & 38 & (HYNIC)-Anx & ? & Kartachova MS ${ }^{84}$ \\
\hline 24 & Breast cancer & 10 & $\begin{array}{l}\text { 99mTc-ethylenedicysteine } \\
\text { Anx }\end{array}$ & ? & Kurihara $\mathrm{H}$ et al. ${ }^{85}$ \\
\hline 25 & Head and neck cancers & 24 & (HYNIC)-Anx & & Hoebers Fj ${ }^{86}$ \\
\hline
\end{tabular}

Intravenous Annexin $\mathrm{V}$ has been shown to be safe and non-toxic in over 25 clinical trials summarised above. 
dramatically reduce the duration of glaucoma clinical studies, which currently have to use visual field status as a key endpoint and determinant of outcome. Finally, it could provide a real-time and objective method by which to monitor not only progression of glaucoma disease, but also response to treatment. It may also serve as a new method of assessing CNS degeneration. In short, DARC may provide the biomarker that we have been searching for and undoubtedly need in glaucoma.

\section{Conflict of interest}

M Francesca Cordeiro, Frederick W Fitzke and Stephen E Moss have a patent application concerning the technology described.

\section{References}

1 Cordeiro MF, Guo L, Luong V, Harding G, Wang W, Jones HE et al. Real-time imaging of single nerve cell apoptosis in retinal neurodegeneration. Proc Natl Acad Sci USA 2004; 101(36): 13352-13356.

2 Garcia-Valenzuela E, Shareef S, Walsh J, Sharma SC. Programmed cell death of retinal ganglion cells during experimental glaucoma. Exp Eye Res 1995; 61(1): 33-44.

3 Quigley HA, Nickells RW, Kerrigan LA, Pease ME, Thibault DJ, Zack DJ. Retinal ganglion cell death in experimental glaucoma and after axotomy occurs by apoptosis. Invest Ophthalmol Vis Sci 1995; 36(5): 774-786.

4 Kerrigan LA, Zack DJ, Quigley HA, Smith SD, Pease ME. TUNEL-positive ganglion cells in human primary openangle glaucoma. Arch Ophthalmol 1997; 115(8): 1031-1035.

5 Qu J, Wang D, Grosskreutz CL. Mechanisms of retinal ganglion cell injury and defense in glaucoma. Exp Eye Res 2010; 91(1): 48-53.

6 Weinreb RN, Friedman DS, Fechtner RD, Cioffi GA, Coleman AL, Girkin CA et al. Risk assessment in the management of patients with ocular hypertension. Am J Ophthalmol 2004; 138(3): 458-467.

7 Kerrigan-Baumrind L, Quigley H, Pease M, Kerrigan D, Mitchell R. Number of ganglion cells in glaucoma eyes compared with threshold visual field tests in the same persons. Invest Ophthalmol Vis Sci 2000; 41: 741-748.

8 Zeyen T. Target pressures in glaucoma. Bull Soc Belge Ophtalmol 1999; 274: 61-65.

9 Harwerth RS, Crawford ML, Frishman LJ, Viswanathan S, Smith III EL, Carter-Dawson L. Visual field defects and neural losses from experimental glaucoma. Prog Retin Eye Res 2002; 21(1): 91-125.

10 Guo L, Moss SE, Alexander RA, Ali RR, Fitzke FW, Cordeiro MF. Retinal ganglion cell apoptosis in glaucoma is related to intraocular pressure and IOP-induced effects on extracellular matrix. Invest Ophthalmol Vis Sci 2005; 46(1): 175-182.

11 Guo L, Salt TE, Maass A, Luong V, Moss SE, Fitzke FW et al. Assessment of neuroprotective effects of glutamate modulation on glaucoma-related retinal ganglion cell apoptosis in vivo. Invest Ophthalmol Vis Sci 2006; 47(2): 626-633.
12 Guo L, Salt TE, Luong V, Wood N, Cheung W, Maass A et al. Targeting amyloid-beta in glaucoma treatment. Proc Natl Acad Sci USA 2007; 104(33): 13444-13449.

13 Maass A, von Leithner PL, Luong V, Guo L, Salt TE, Fitzke FW et al. Assessment of rat and mouse RGC apoptosis imaging in vivo with different scanning laser ophthalmoscopes. Curr Eye Res 2007; 32(10): 851-861.

14 Guo L, Cordeiro MF. Assessment of neuroprotection in the retina with DARC. Prog Brain Res 2008; 173: 437-450.

15 Cheung W, Guo L, Cordeiro MF. Neuroprotection in glaucoma: drug-based approaches. Optom Vis Sci 2008; 85(6): 406-416.

16 Vermes I, Haanen C, Steffens-Nakken H, Reutelingsperger C. A novel assay for apoptosis. Flow cytometric detection of phosphatidylserine expression on early apoptotic cells using fluorescein labelled Annexin V. J Immunol Methods 1995; 184(1): 39-51.

17 Narula J, Acio ER, Narula N, Samuels LE, Fyfe B, Wood D et al. Annexin-V imaging for noninvasive detection of cardiac allograft rejection. Nat Med 2001; 7(12): 1347-1352.

18 Zhao M, Beauregard DA, Loizou L, Davletov B, Brindle KM. Non-invasive detection of apoptosis using magnetic resonance imaging and a targeted contrast agent. Nat Med 2001; 7(11): 1241-1244.

19 Blankenberg FG, Strauss HW. Will imaging of apoptosis play a role in clinical care? A tale of mice and men. Apoptosis 2001; 6(1-2): 117-123.

20 Green AM, Steinmetz ND. Monitoring apoptosis in real time. Cancer J 2002; 8(2): 82-92.

21 Flotats A, Carrio I. Non-invasive in vivo imaging of myocardial apoptosis and necrosis. Eur J Nucl Med Mol Imaging 2003; 30(4): 615-630.

22 Mountz JD, Hsu HC, Wu Q, Liu HG, Zhang HG, Mountz JM. Molecular imaging: new applications for biochemistry. J Cell Biochem Suppl 2002; 39: 162-171.

23 Reutelingsperger CP, Dumont E, Thimister PW, van Genderen $\mathrm{H}$, Kenis $\mathrm{H}$, van de Eijnde $\mathrm{S}$ et al. Visualization of cell death in vivo with the annexin A5 imaging protocol. J Immunol Methods 2002; 265(1-2): 123-132.

24 Wade AR, Fitzke FW. A fast, robust pattern recognition system for low light level image registration and its application to retinal imaging. Optics Express 1998; 3(5): 190-197.

25 von Ruckmann A, Fitzke FW, Bird AC. Distribution of fundus autofluorescence with a scanning laser ophthalmoscope. Br J Ophthalmol 1995; 79(5): 407-412.

26 Schmitz-Valckenberg S, Guo L, Maass A, Cheung W, Vugler A, Moss SE et al. Real-time in-vivo imaging of retinal cell apoptosis after laser exposure. Invest Ophthalmol Vis Sci 2008; 49(6): 2773-2780.

27 Cordeiro MF, Guo L, Coxon KM, Duggan J, Nizari S, Normando EM et al. Imaging multiple phases of neurodegeneration: a novel approach to assessing cell death in vivo. Cell Death and Disease 2010; 1(1): e3-e14.

28 Fitzke F. Imaging the optic nerve and ganglion cell layer. Eye 2000; 14: 450-453.

29 Nickells RW. Apoptosis of retinal ganglion cells in glaucoma: an update of the molecular pathways involved in cell death. Surv Ophthalmol 1999; 43(Suppl 1): S151-S161.

30 Tatton NA, Tezel G, Insolia SA, Nandor SA, Edward PD, Wax MB. In situ detection of apoptosis in normal pressure glaucoma. a preliminary examination. Surv Ophthalmol 2001; 45(Suppl 3): S268-S272; discussion S73-S76. 
31 Reichstein D, Ren L, Filippopoulos T, Mittag T, Danias J. Apoptotic retinal ganglion cell death in the DBA/ 2 mouse model of glaucoma. Exp Eye Res 2007; 84(1): 13-21.

32 Kanamori A, Catrinescu MM, Kanamori N, Mears KA, Beaubien R, Levin LA. Superoxide is an associated signal for apoptosis in axonal injury. Brain 2010; 133(9): 2612-2625.

33 Morrison JC, Moore CG, Deppmeier LM, Gold BG, Meshul CK, Johnson EC. A rat model of chronic pressureinduced optic nerve damage. Exp Eye Res 1997; 64(1): 85-96.

34 Shareef S, Garcia-Valenzuela E, Salierno A, Walsh J, Sharma S. Chronic ocular hypertension following episcleral venous occlusion in rats. Exp Eye Res 1995; 61: 379-382.

35 WoldeMussie E, Ruiz G, Wijono M, Wheeler LA. Neuroprotection of retinal ganglion cells by brimonidine in rats with laser-induced chronic ocular hypertension. Invest Ophthalmol Vis Sci 2001; 42(12): 2849-2855.

36 Ueda J, Sawaguchi S, Hanyu T, Yaoeda K, Fukuchi T, Abe H et al. Experimental glaucoma model in the rat induced by laser trabecular photocoagulation after an intracameral injection of India ink. Jpn J Ophthalmol 1998; 42(5): 337-344.

37 Levkovitch-Verbin H, Quigley HA, Martin KR, Valenta D, Baumrind LA, Pease ME. Translimbal laser photocoagulation to the trabecular meshwork as a model of glaucoma in rats. Invest Ophthalmol Vis Sci 2002; 43(2): 402-410.

38 Sawada A, Neufeld A. Confirmation of the rat model of chronic, moderately elevated intraocular pressure. Exp Eye Res 1999; 69: 525-531.

39 Mittag TW, Danias J, Pohorenec G, Yuan HM, Burakgazi E, Chalmers-Redman $\mathrm{R}$ et al. Retinal damage after 3-4 months of elevated intraocular pressure in a rat glaucoma model. Invest Ophthalmol Vis Sci 2000; 41(11): 3451-3459.

40 Naskar R, Wissing M, Thanos S. Detection of early neuron degeneration and accompanying microglial responses in the retina of a rat model of glaucoma. Invest Ophthalmol Vis Sci 2002; 43(9): 2962-2968.

41 Bayer AU, Danias J, Brodie S, Maag KP, Chen B, Shen F et al. Electroretinographic abnormalities in a rat glaucoma model with chronic elevated intraocular pressure. Exp Eye Res 2001; 72(6): 667-677.

42 Agar A, Yip SS, Hill MA, Coroneo MT. Pressure related apoptosis in neuronal cell lines. J Neurosci Res 2000; 60(4): 495-503.

43 Levkovitch-Verbin H, Quigley HA, Kerrigan-Baumrind LA, D'Anna SA, Kerrigan D, Pease ME. Optic nerve transection in monkeys may result in secondary degeneration of retinal ganglion cells. Invest Ophthalmol Vis Sci 2001; 42(5): 975-982.

44 Harwerth RS, Wheat JL, Rangaswamy NV. Age-related losses of retinal ganglion cells and axons. Invest Ophthalmol Vis Sci 2008; 49(10): 4437-4443.

45 Jonas JB, Schmidt AM, Muller-Bergh JA, SchlotzerSchrehardt UM, Naumann GO. Human optic nerve fiber count and optic disc size. Invest Ophthalmol Vis Sci 1992; 33(6): 2012-2018.

46 Harman A, Abrahams B, Moore S, Hoskins R. Neuronal density in the human retinal ganglion cell layer from 16 to 77 years. Anat Rec 2000; 260(2): 124-131.

47 Neufeld AH, Gachie EN. The inherent, age-dependent loss of retinal ganglion cells is related to the lifespan of the species. Neurobiol Aging 2003; 24(1): 167-172.

48 Danias J, Lee KC, Zamora MF, Chen B, Shen F, Filippopoulos T et al. Quantitative analysis of retinal ganglion cell (RGC) loss in aging DBA/2NNia glaucomatous mice: comparison with RGC loss in aging C57/BL6 mice. Invest Ophthalmol Vis Sci 2003; 44(12): 5151-5162.

49 Cone FE, Gelman SE, Son JL, Pease ME, Quigley HA. Differential susceptibility to experimental glaucoma among 3 mouse strains using bead and viscoelastic injection. Exp Eye Res 2010; 91(3): 415-424.

50 Okisaka S, Murakami A, Mizukawa A, Ito J. Apoptosis in retinal ganglion cell decrease in human glaucomatous eyes. Jpn J Ophthalmol 1997; 41(2): 84-88.

51 Schmitz-Valckenberg S, Guo L, Maass A, Cheung W, Vugler A, Moss SE et al. Real-time in vivo imaging of retinal cell apoptosis after laser exposure. Invest Ophthalmol Vis Sci 2008; 49(6): 2773-2780.

52 Oliver JE, Hattenhauer MG, Herman D, Hodge DO, Kennedy R, Fang-Yen M et al. Blindness and glaucoma: a comparison of patients progressing to blindness from glaucoma with patients maintaining vision. Am J Ophthalmol 2002; 133(6): 764-772.

53 Collaborative Normal-Tension Glaucoma Study Group T. Comparison of glaucomatous progression between untreated patients with normal-tension glaucoma and patients with therapeutically reduced intraocular pressures. Collaborative Normal-Tension Glaucoma Study Group. Am J Ophthalmol 1998; 126(4): 487-497.

54 Osborne NN, Ugarte M, Chao M, Chidlow G, Bae JH, Wood JP et al. Neuroprotection in relation to retinal ischemia and relevance to glaucoma. Surv Ophthalmol 1999; 43(Suppl 1): S102-S128.

55 Lipton SA. Paradigm shift in NMDA receptor antagonist drug development: molecular mechanism of uncompetitive inhibition by memantine in the treatment of Alzheimer's disease and other neurologic disorders. J Alzheimers Dis 2004; 6(6 Suppl): S61-S74.

56 Farlow MR. NMDA receptor antagonists. A new therapeutic approach for Alzheimer's disease. Geriatrics 2004; 59(6): 22-27.

57 Hare W, WoldeMussie E, Lai R, Ton H, Ruiz G, Feldmann B et al. Efficacy and safety of memantine, an NMDA-type open-channel blocker, for reduction of retinal injury associated with experimental glaucoma in rat and monkey. Surv Ophthalmol 2001; 45(Suppl 3): S284-S289; discussion S95-S96.

58 WoldeMussie E, Yoles E, Schwartz M, Ruiz G, Wheeler LA. Neuroprotective effect of memantine in different retinal injury models in rats. J Glaucoma 2002; 11(6): 474-480.

59 Quinn R. Comparing rat's to human's age: how old is my rat in people years? Nutrition (Burbank, Los Angeles County, Calif) 2005; 21(6): 775-777.

60 Schuettauf F, Rejdak R, Walski M, Frontczak-Baniewicz M, Voelker M, Blatsios G et al. Retinal neurodegeneration in the DBA/2J mouse-a model for ocular hypertension. Acta Neuropathol 2004; 107(4): 352-358.

61 Jakobs TC, Libby RT, Ben Y, John SW, Masland RH. Retinal ganglion cell degeneration is topological but not cell type specific in DBA/2J mice. J Cell Biol 2005; 171(2): 313-325.

62 Lei Y, Garrahan N, Hermann B, Fautsch MP, Johnson DH, Hernandez MR et al. Transretinal degeneration in ageing human retina: a multiphoton microscopy analysis. $\mathrm{Br} \mathrm{J}$ Ophthalmol 2010; e-pub ahead of print 22 December 2010.

63 Hofstra L, Liem IH, Dumont EA, Boersma HH, van Heerde WL, Doevendans PA et al. Visualisation of cell 
death in vivo in patients with acute myocardial infarction. Lancet 2000; 356(9225): 209-212.

64 Hofstra L, Dumont EA, Thimister PW, Heidendal GA, DeBruine AP, Elenbaas TW et al. In vivo detection of apoptosis in an intracardiac tumor. Jama 2001; 285(14): 1841-1842.

65 Belhocine T, Steinmetz N, Hustinx R, Bartsch P, Jerusalem G, Seidel L et al. Increased uptake of the apoptosis-imaging agent $(99 \mathrm{~m}) \mathrm{Tc}$ recombinant human Annexin V in human tumors after one course of chemotherapy as a predictor of tumor response and patient prognosis. Clin Cancer Res 2002; 8(9): 2766-2774.

66 Boersma HH, Liem IH, Kemerink GJ, Thimister PW, Hofstra L, Stolk LM et al. Comparison between human pharmacokinetics and imaging properties of two conjugation methods for 99mTc-annexin A5. Br J Radiol 2003; 76(908): 553-560.

67 Kemerink GJ, Liu X, Kieffer D, Ceyssens S, Mortelmans L, Verbruggen AM et al. Safety, biodistribution, and dosimetry of 99mTc-HYNIC-annexin V, a novel human recombinant annexin V for human application. J Nucl Med 2003; 44(6): 947-952.

68 van de Wiele C, Lahorte C, Vermeersch H, Loose D, Mervillie K, Steinmetz ND et al. Quantitative tumor apoptosis imaging using technetium-99m-HYNIC annexin V single photon emission computed tomography. J Clin Oncol 2003; 21(18): 3483-3487.

69 Lahorte CM, van de Wiele C, Bacher K, van den Bossche B, Thierens $\mathrm{H}$, van Belle $\mathrm{S}$ et al. Biodistribution and dosimetry study of 123I-rh-annexin $\mathrm{V}$ in mice and humans. Nucl Med Commun 2003; 24(8): 871-880.

70 Thimister PW, Hofstra L, Liem IH, Boersma HH, Kemerink G, Reutelingsperger CP et al. In vivo detection of cell death in the area at risk in acute myocardial infarction. J Nucl Med 2003; 44(3): 391-396.

71 Kartachova M, Haas RL, Olmos RA, Hoebers FJ, van Zandwijk N, Verheij M. In vivo imaging of apoptosis by 99mTc-Annexin V scintigraphy: visual analysis in relation to treatment response. Radiother Oncol 2004; 72(3): 333-339.

72 Kietselaer BL, Reutelingsperger CP, Heidendal GA, Daemen MJ, Mess WH, Hofstra L et al. Noninvasive detection of plaque instability with use of radiolabeled annexin A5 in patients with carotid-artery atherosclerosis. N Engl J Med 2004; 350(14): 1472-1473.

73 Vermeersch H, Ham H, Rottey S, Lahorte C, Corsetti F, Dierckx R et al. Intraobserver, interobserver, and day-to-day reproducibility of quantitative $99 \mathrm{mTc}-\mathrm{HYNIC}$ annexin-V imaging in head and neck carcinoma. Cancer Biother Radiopharm 2004; 19(2): 205-210.

74 Vermeersch H, Loose D, Lahorte C, Mervillie K, Dierckx R, Steinmetz $\mathrm{N}$ et al. 99mTc-HYNIC Annexin-V imaging of primary head and neck carcinoma. Nucl Med Commun 2004; 25(3): 259-263.

75 Vermeersch H, Mervillie K, Lahorte C, Loose D, Dierck RA, Steinmetz N et al. Relationship of 99mTc-HYNIC annexin V uptake to microvessel density, FasL and MMP-9 expression, and the number of tumour-infiltrating lymphocytes in head and neck carcinoma. Eur J Nucl Med Mol Imaging 2004; 31(7): 1016-1021.

76 Haas RL, de Jong D, Valdes Olmos RA, Hoefnagel CA, van den Heuvel I, Zerp SF et al. In vivo imaging of radiation-induced apoptosis in follicular lymphoma patients. Int J Radiat Oncol Biol Phys 2004; 59(3): 782-787.

77 Rongen GA, Oyen WJ, Ramakers BP, Riksen NP, Boerman OC, Steinmetz $\mathrm{N}$ et al. Annexin A5 scintigraphy of forearm as a novel in vivo model of skeletal muscle preconditioning in humans. Circulation 2005; 111(2): 173-178.

78 Lampl Y, Lorberboym M, Blankenberg FG, Sadeh M, Gilad R. Annexin V SPECT imaging of phosphatidylserine expression in patients with dementia. Neurology 2006; 66(8): 1253-1254.

79 Lorberboym M, Blankenberg FG, Sadeh M, Lampl Y. In vivo imaging of apoptosis in patients with acute stroke: correlation with blood-brain barrier permeability. Brain Res 2006; 1103(1): 13-19.

80 Kartachova MS, Valdes Olmos RA, Haas RL, Hoebers FJ, van den Brekel MW, van Zandwijk $\mathrm{N}$ et al. Mapping of treatment-induced apoptosis in normal structures: 99mTcHynic-rh-annexin V SPECT and CT image fusion. Eur J Nucl Med Mol Imaging 2006; 33(8): 893-899.

81 Kartachova M, van Zandwijk N, Burgers S, van Tinteren H, Verheij M, Valdes Olmos RA. Prognostic significance of 99mTc Hynic-rh-annexin V scintigraphy during platinumbased chemotherapy in advanced lung cancer. J Clin Oncol 2007; 25(18): 2534-2539.

82 Kietselaer BL, Reutelingsperger CP, Boersma HH, Heidendal GA, Liem IH, Crijns HJ et al. Noninvasive detection of programmed cell loss with $99 \mathrm{mTc}$-labeled annexin A5 in heart failure. J Nucl Med 2007; 48(4): 562-567.

83 Van den Brande JM, Koehler TC, Zelinkova Z, Bennink RJ, te Velde AA, ten Cate FJ et al. Prediction of antitumour necrosis factor clinical efficacy by real-time visualisation of apoptosis in patients with Crohn's disease. Gut 2007; 56(4): 509-517.

84 Kartachova MS, Valdes Olmos RA, Haas RL, Hoebers FJ, van Herk M, Verheij M. 99mTc-HYNIC-rh-annexin-V scintigraphy: visual and quantitative evaluation of early treatment-induced apoptosis to predict treatment outcome. Nucl Med Commun 2008; 29(1): 39-44

85 Kurihara H, Yang DJ, Cristofanilli M, Erwin WD, Yu DF, Kohanim $S$ et al. Imaging and dosimetry of $99 \mathrm{mTc}$ EC annexin V: preliminary clinical study targeting apoptosis in breast tumors. Appl Radiat Isot 2008; 66(9): 1175-1182.

86 Hoebers FJ, Kartachova M, de Bois J, van den Brekel MW, van Tinteren $H$, van Herk $M$ et al. 99mTc Hynic-rh-Annexin $\mathrm{V}$ scintigraphy for in vivo imaging of apoptosis in patients with head and neck cancer treated with chemoradiotherapy. Eur J Nucl Med Mol Imaging 2008; 35(3): 509-518. 